Article

\title{
Implementation of Nature-Based Solutions for Hydro-Meteorological Risk Reduction in Small Mediterranean Catchments: The Case of Portofino Natural Regional Park, Italy
}

\author{
Laura Turconi ${ }^{1}\left(\mathbb{D}\right.$, Francesco Faccini ${ }^{1,2, *} \mathbb{0}$, Alessandra Marchese ${ }^{3}$, Guido Paliaga ${ }^{1}(\mathbb{D}$, \\ Marco Casazza ${ }^{4, *(\mathbb{D})}$, Zoran Vojinovic ${ }^{5}$ and Fabio Luino ${ }^{1}$ (D) \\ 1 Istituto di Ricerca per la Protezione Idrogeologica, Consiglio Nazionale delle Ricerche, Strada della Cacce 73, \\ 10135 Torino, Italy; laura.turconi@irpi.cnr.it (L.T.); guido.paliaga@irpi.cnr.it (G.P.); \\ fabio.luino@irpi.cnr.it (F.L.) \\ 2 Dipartimento di Scienze della Terra dell'Ambiente e della Vita, Università di Genova, Corso Europa 26, \\ 16132 Genova, Italy \\ 3 Geographical Information System International Group (GISIG), Via Piacenza 54, 16138 Genoa, Italy; \\ a.marchese@gisig.it \\ 4 Department of Engineering, Parthenope University of Naples, Via Amm. F. Acton 38, 80133 Naples, Italy \\ 5 IHE Delft Institute for Water Education, Westvest 7, 2611 AX Delft, The Netherlands; z.vojinovic@un-ihe.org \\ * Correspondence: faccini@unige.it (F.F.); marco.casazza@uniparthenope.it (M.C.)
}

Received: 10 December 2019; Accepted: 6 February 2020; Published: 8 February 2020

check for updates

\begin{abstract}
Nature-based solutions (NBS) are usually defined as complementary or alternative solutions to "grey infrastructures" (traditionally made with cement) aimed at conserving and regenerating the functionality of natural and semi-natural ecosystems. The research to date shows a considerable potential of NBS to address the current challenges related to climate change and geo-hydrological risks. Despite significant interest in NBS by researchers and practitioners, knowledge concerning their practical implementation, monitoring, and evaluation is still lacking. This is particularly true for large-scale NBS. The present paper discusses how such solutions can be implemented in the context of hydro-meteorological risk reduction in small Mediterranean catchments with a strong tourist vocation. The work presented here is situated within the RECONECT Project (Regenerating ECOsystems with Nature-based solutions for hydro-meteorological risk rEduCTion), which aims to contribute to a European reference framework on NBS by demonstrating, upscaling, and replicating large-scale NBS in rural and natural areas. The Italian case study of RECONECT is the Portofino Natural Regional Park, which represents a unique natural landscape element with high ecologic, social, and economic (touristic) value, which is threatened by a range of geo-hydrological hazards, such as flash floods, hyper-concentrated floods, shallow landslides, rockfalls, and storm surges. This paper also presents details of NBS interventions in two pilot catchments (San Fruttuoso and Paraggi) visited by thousands of tourists throughout the year. It addresses some of the key aspects related to monitoring meteorological and hydrological processes, as well as remote sensing activities (i.e., LiDAR surveys), which are necessary for the identification of critical-instability areas along waterways and the reconstruction of dry stone walls. Lastly, a discussion of relevant mitigation and adaptation strategies that are potentially replicable at national and international levels is also provided.
\end{abstract}

Keywords: nature-based solutions; hydro-meteorological risk reduction; Portofino Natural Regional Park, Liguria; Italy 


\section{Introduction}

The European Commission defines nature-based solutions (NBS) as "solutions that aim to help societies address a variety of environmental, social and economic challenges in sustainable ways. They are actions inspired by, supported by or copied from nature [ ... ]. Nature-Based Solutions use features and natural processes, such as its ability to store carbon and regulate water flows, in order to achieve desired outcomes [ ... ]" [1]. With respect to geo-hydrological risk, including the impact of floods, erosion, mass transport of debris flow, and triggering landslides, we can distinguish several types of NBS [2] that may be suitable for different environmental conditions [3]. These NBS can be implemented to reduce impacts and bring benefits with respect to (a) water management (i.e., reducing flood risks, storing and infiltrating rainfall run-off, reducing erosion); (b) society (i.e., an increased esthetic value of the area, e.g., increasing tourism, walking, jogging, cycling); (c) economics (i.e., reducing the damage from geo-hydrological events, energy saving); and (d) the environment (i.e., reducing air and noise pollution).

A single NBS site can be considered and evaluated either on its own or in combination with other NBS [3]. Combinations can also be created between one or more NBS with grey infrastructures, which are usually referred to as hybrid solutions [4,5], and these configurations sometimes give the most effective results. Some studies have shown that NBS are likely to be more effective when implemented through cooperation with local people and with a good governance model [6].

Small scale NBS [2] are usually applied to a single site or relatively small areas such as a single building or a street. Examples of small-scale NBS are green roofs, rain gardens, small-scale detention or retention ponds, permeable pavements, bio-retention, and vegetated swales. Large-scale NBS [2] are usually represented by either large-scale, single interventions or a number of different NBS interconnected within a larger hydrological system. An effective example of large-scale NBS implementation is the Dutch "Room for the River Program", which involved 39 local projects based on nine different types of measures. This program not only achieved benefits in terms of flood risk reduction, but it also produced other benefits, including improvements in spatial quality as well as habitat and biodiversity restoration [7,8]. Another case study is the Laojiee River Project in Taiwan, where the channelized watercourse was changed into an accessible green infrastructure corridor for the public, increasing recreation activities and the value of the area [9].

The process of implementing NBS is rather complex and it requires the active involvement of stakeholders that often have conflicting interests. A typical decision-making process concerning the implementation of NBS is based on three main steps [1-3]: (1) selection, which takes into consideration the characteristics of the site, land use, governance aspects, and environmental needs; (2) evaluation, through performance indicators; and (3) optimization, to select optimal NBS configurations according to the particular situation.

There is a need for more research efforts in terms of assessing the costs and benefits of large-scale NBS and to test their efficacy in different landscape contexts. To boost such a research and evidence base, the European Commission (EC) is financing several projects within the Horizon 2020 Framework Program. The first EC-funded large-scale NBS projects are RECONECT (http://www.reconect.eu/), PHUSICOS [10], and OPERANDUM [11].

The RECONECT ("Regenerating ECOsystems with Nature-based solutions for hydro-meteorological risk rEduCTion") project aims to (1) demonstrate several large-scale NBS through implementation, as well as monitoring and evaluation of their effectiveness for reducing hydro-meteorological risks; (2) develop an information and communication technology platform that provides real-time information about the performance of the NBS, as well as the necessary evidence to facilitate their planning, replication, and upscaling; (3) define a roadmap (including investment strategies and business models) for NBS implementation and operation; and (4) apply this roadmap to several cases in Europe and beyond. This project brings together 35 international project partners, 10 demonstration sites in Europe, and 18 European and International Collaborator sites to showcase the benefits of NBS for hydro-meteorological risk reduction. These sites were selected to cover a wide 
and diverse range of local conditions, geographic characteristics, institutional/governance structures, and social/cultural settings to successfully upscale NBS both throughout Europe and internationally.

This present paper discusses some important aspects concerning the design, implementation, monitoring, and evaluation of large-scale NBS in the Portofino Natural Regional Park (Liguria, Italy), which is part of the RECONECT project. This area is known for its high natural capital and cultural heritage values. Moreover, the anthropic pressure of the surrounding urbanized areas and the frequency of extreme geo-hydrological events make this area vulnerable and particularly interesting for the application of NBS. In what follows, we describe the Portofino case study site, the type of NBS being implemented, the monitoring activities, and the selection of indicators for assessing NBS performance.

\section{Portofino Case Study Site}

\subsection{The RECONECT Project Case Studies}

The RECONECT project combines ten demonstration cases which are divided in two groups (Figure 1): Demonstrators Type A (four cases), for which the NBS sites need to be constructed and monitored within the project lifetime; and Demonstrators Type B (six cases), for which the NBS sites have already been implemented and will also be monitored, evaluated, and validated during the lifetime of the project.

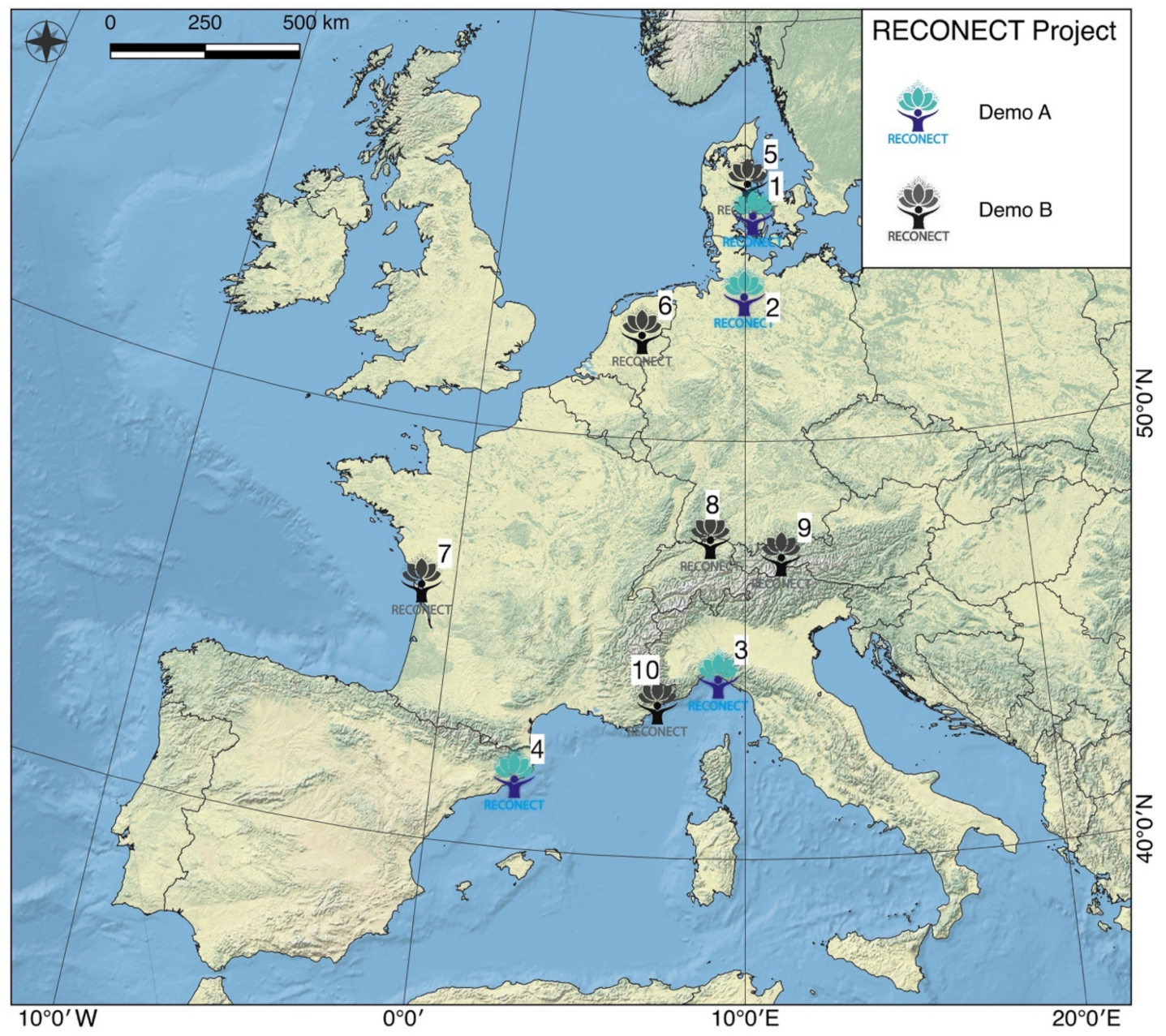

Figure 1. Network of ten demonstration cases in the RECONECT Project. (1) Seden Strand, Odense, Denmark; (2) Elbe Estuary, Germany; (3) Portofino Natural Regional Park, Italy; (4) Tordera River Basin, Catalonia; (5) Greater Aarhus, Denmark; (6) Ijssel River basin, the Netherlands; (7) Les Boucholeurs, France; (8) Thur River Basin, Switzerland; (9) Inn River Basin, Austria; and (10) Var River Basin, France. 
The project aims to demonstrate a variety of solutions in relation to hydro-meteorological risk reduction [2,3]. The RECONECT NBS evaluation framework starts from ten challenges defined in the EC-funded EKLIPSE project (http://www.eklipse-mechanism.eu/nbs_report) and combines them into three categories, namely, water, nature, and people, to assess their benefits and co-benefits (http://www.reconect.eu/).

\subsection{Portofino Natural Regional Park}

The Portofino Promontory (Liguria, Italy) is situated between Genoa and the border with Tuscany. The promontory encompasses an area of $18 \mathrm{~km}^{2}$, with a coastal development of $13 \mathrm{~km}$. The terrain topography is rather mountainous, with high elevations over a short distance from the coastline (e.g., Mt. Portofino with elevations of $610 \mathrm{~m}$ above sea level). The overall basin is comprised of several smaller basins with surface areas of less than $1 \mathrm{~km}^{2}$ and streams along the steep slopes (mostly of the $2^{\circ}$ sensu Strahler order [12]). Within this area, there also smaller areas such as Cala d'Oro, Rio dei Fontanini, San Fruttuoso, Ruffinale, and Vessinaro, which can only be reached by sea or by hiking trails, i.e., there is no road access (see Figure 2A). Along the eastern part of this area, there are two creeks: the Fondaco creek and the Acqua Viva creek (see also Figure 2A).

Table 1. Main features of the hydrographical network in the San Fruttuoso and Paraggi catchments (see also Figure 2A).

\begin{tabular}{ccccccc}
\hline Catchment & Area $\left.\mathbf{( k m}^{\mathbf{2}}\right)$ & $\begin{array}{c}\text { Perimeter } \\
\mathbf{( k m )}\end{array}$ & $\begin{array}{c}\text { Mean } \\
\text { steepness (\%) }\end{array}$ & $\begin{array}{c}\text { Terraced } \\
\text { surface (\%) }\end{array}$ & $\begin{array}{c}\text { Hydrographical } \\
\text { network length (km) }\end{array}$ & $\begin{array}{c}\text { Main stream } \\
\text { length }(\mathbf{k m})\end{array}$ \\
\hline 1-Rio dei Fontanini & 0.585 & 3.507 & 70 & 2.5 & 2.825 & 1.142 \\
\hline 2-Vallone di San Fruttuoso & 0.444 & 2.945 & 64 & 9.4 & 1.953 & 0.838 \\
\hline $\begin{array}{l}\text { 3-Fosso dell'Acqua Viva (also } \\
\text { known as Paraggi Catchment) }\end{array}$ & 1.480 & 5.330 & 51 & 70 & 7.509 & 1.836 \\
\hline
\end{tabular}

The Portofino Natural Regional Park (Figure 2), internationally renowned for its beauty and the high values of the settlements, vegetation, and geomorphology [13], protects the area of the promontory with the same name, located approximately $20 \mathrm{~km}$ away from the city of Genoa. With respect to the landscape and cultural values, Law 1251 has protected the Promontory of Portofino since 1935. Since 1995, this area has been managed by the park authority established by Regional Law 12/95, and the boundaries of the protected area have been redefined by Regional Law 29/2001 [14].

The Portofino Natural Regional Park's main mission is the conservation of nature and biodiversity. Being exposed to frequent and intense hydro-meteorological events, this area requires not only effective flood protection but also sustainable solutions that can achieve the park's main mission. Consequently, the challenge for this area within the RECONECT project is to demonstrate NBS for risk reduction in an integrated context of conservation and innovation. The intense urbanization that is taking place in many areas of the Liguria region also occupies some natural areas for which NBS may be helpful in regaining balance and harmony with nature. The high adaptability of NBS may be crucial in an area dominated by high-energy processes, which influence a complex and heterogeneous morphology.

The area of the Portofino Natural Regional Park spreads over several municipalities (Camogli, Portofino, Santa Margherita Ligure, and Rapallo; see Figure 2A). The first human settlements in the area date back to Roman times. In the Middle Age, several important religious buildings were constructed (e.g., San Fruttuoso), connected by historical trails that are still in use today [13,14]. The recent census shows an estimated population of about 750 inhabitants.

This area is very popular for tourism throughout the year. Every year, over a million tourists visit the small town of Portofino, while the nearby town of San Fruttuoso receives about 400,000 tourists from the sea by boats. There are also a considerable number of hikers that come to this area, together with the tourists (see Figure 2B), and the hiking paths extend over $80 \mathrm{~km}$ in length [15]. 

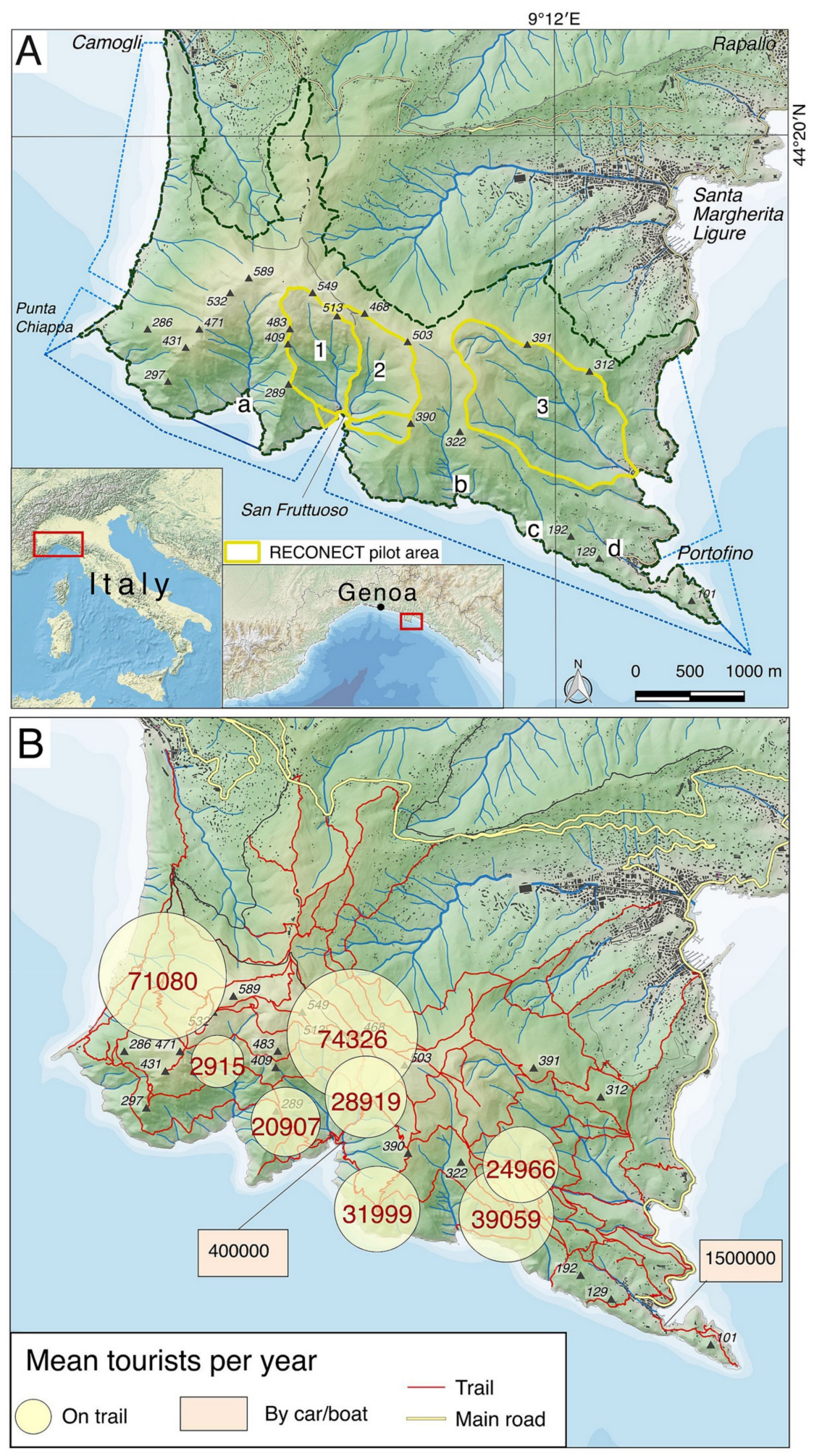

Figure 2. A map of Portofino Promontory with selected catchments for nature-based solution (NBS) interventions. (A) The Portofino Natural Regional Park boundary (dotted line): Rio dei Fontanini (1) and Vallone di San Fruttuoso (2) catchments, as well as Fosso dell'Acqua Viva (3), also known as Paraggi Catchment, are shown (see Table 1). Other catchments: (a) Cala d'Oro, (b) Ruffinale, (c) Vessinaro, (d) Fondaco. (B) The average number of annual tourists along the trails within the Portofino Natural Regional Park. 


\subsection{Portofino's Climate, Geology, and Geomorphology}

The Portofino Natural Regional Park has a typical Mediterranean climate (Csa: Hot summer Mediterranean climate, sensu Koppen [16,17]), characterized by hot summers (July $\mathrm{T}_{\max } 27^{\circ} \mathrm{C}$ and $\mathrm{T}_{\min } 21^{\circ} \mathrm{C}$ ) and mild winters (January $\mathrm{T}_{\max } 11^{\circ} \mathrm{C}$ and $\mathrm{T}_{\min } 5^{\circ} \mathrm{C}$ ). The average annual rainfall is around $1300 \mathrm{~mm}$, which occurs in autumn. The climatic condition of this area is characterized by phenomena linked to cyclogenesis on the Gulf of Genoa [18]. Especially in the period between August and November, there are frequent intense rainfall events with short duration and high peaks $(<6$ hours, with peaks above $50 \mathrm{~mm} / \mathrm{h}$ ), which often cause significant impacts through flash floods, landslides, and mud-debris flow.

Within the RECONECT project, demonstration activities will be carried out in the following three catchments: two San Fruttuoso catchments (Rio dei Fontanini and Vallone di San Fruttuoso) and a Paraggi catchment (Fosso dell'Acqua Viva) (see Figure 2A). The three small catchments of the case study area, due to its morphometric asset [14,15], are characterized by the presence of a stream network with high slopes and irregular discharges. Within the streams of the Rio dei Fontanini and Vallone di San Fruttuoso catchments, a more considerable discharge can be observed only during and after rainfall events, while in the Fosso dell'Acqua Viva stream, there is always a more prominent discharge (see Table 1).

The geology of the Portofino Promontory is characterized by a conglomerate ("puddinga", which means puddingstone) that creates a trapezoidal shape between Punta Chiappa in the west and the Lighthouse of Portofino in the east [19]. The substrate of Mount of Portofino, from Camogli to Rapallo, is characterized by marly limestone flysch [20]. The morphology of the promontory is linked to a structure bounded by direct faults, typical of a continental margin subject to disjunctive tectonics.

The conglomerate of Portofino (Oligocene) is of marly limestone or sandstone, often with thin carbonaceous interlayers; there are also clasts of ophiolites, cherts, and gneiss. The rock mass is affected by several fracture systems, identifiable at the meso- and macro-scale [21]. At the slope scale, the intersection between different fracture systems determines the subdivision of the conglomerate into multi-decametric blocks.

The flysch of Mt. Antola (Cretaceous sup.-Paleocene) is made of marly limestone and marl, with intercalations of shales, siltstones, and calcarenites. The structural feature of the flysch is conditioned by the different deformation phases, both ductile and fragile, registered by the rocky complex. On a large scale, the substrate underwent a ductile deformation and now appears as an isoclinal fold with convergence towards the oriented axis [20,21].

The geological setting and the Mediterranean climate determine the landforms and the geomorphological dynamics in this region. The southern slope of the Portofino Promontory is characterized by rocky cliffs with heights of up to $200 \mathrm{~m}$, which are some of the highest areas in the Mediterranean [22]. The slope angle ranges between $45^{\circ}$ and $65^{\circ}$. The action of the wind is important, coming from both the south-east (Scirocco, reigning wind) and the south-west (Libeccio, dominant wind). Sea storm surges are frequent, involving waves of up to $5 \mathrm{~m}$ in height, and can cause some considerable damage to the surrounding buildings and infrastructure.

Frequent rockfalls occur along the southern slopes. On the western slope, the cliff is formed mainly in the flysch of Mount Antola, with terrain elevations exceeding $100 \mathrm{~m}$. In this area, the frequent waves cause erosion of cliffs and represent one of the triggering factors of rapid landslides or debris flow with high destructive power [22].

There are also frequent landslides in the southern part of the area, which often affect the surrounding buildings and infrastructure (Figure 3) $[15,23]$.

Among the anthropic landforms in the area, there are also terraces with dry stone walls. Their origin and characteristics have previously been described by several authors [23-25]. There are also considerable terraced areas in Paraggi, Portofino, and San Fruttuoso creeks, and they all represent important cultural assets in this area [26]. 


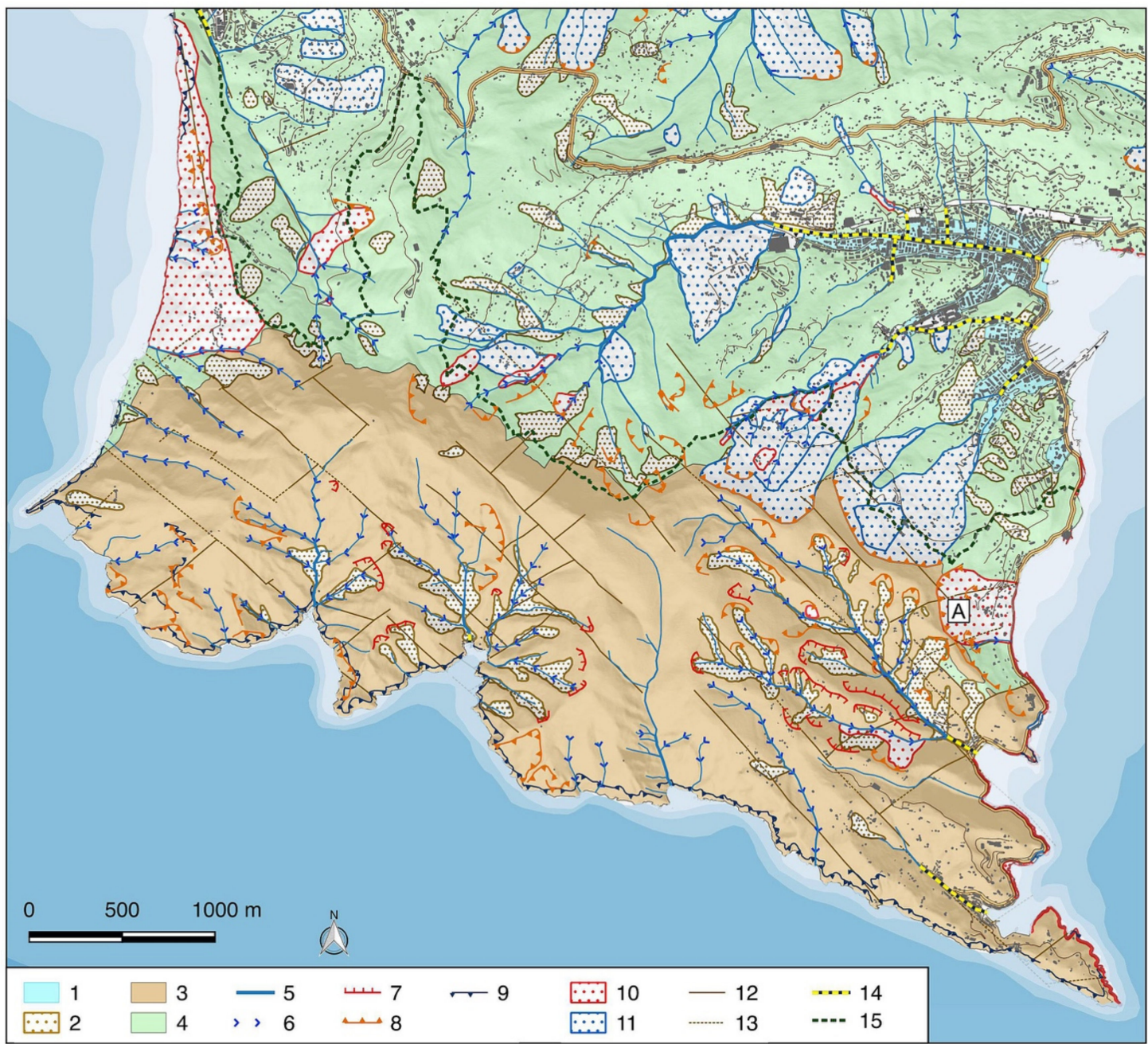

Figure 3. A geomorphological map of the Portofino Promontory: (1) alluvial deposit; (2) debris cover; (3) conglomerates with sandstone layers; (4) marly limestones, clayed marls, and marls; (5) hydrographical network; (6) downcutting talweg; (7) degradation scarp; (8) landslide scarp; (9) cliff; (10) active landslide; (11) inactive landslide; (12) fault; (13) presumed fault; (14) culvert; (15) Portofino Natural Regional Park boundary (map obtained from data survey and data integration of [20-22,26]).

(A) mountain slope deformation.

\subsection{Biotic Components in the Portofino Natural Regional Park}

Due to its landscape and climate features, significant biodiversity of fauna and vegetation characterizes the Portofino Promontory area $[27,28]$. Mediterranean vegetation covers the southern maritime slopes with a predominant presence of evergreen species, adapted to high temperatures and reduced rainfall conditions. The main observable vegetations are the following:

(1) Coast vegetation, covering the cliffs overlooking the Ligurian Sea, which is resistant to salinity and wind. Typical examples are marine fennel (Chrithmummaritimum) and statice cordata (Limonium cordatum). Other small plants are the spiny Euphorbia (Euphorbia spinosa) and specimens of the genus Sedum (for example, S. album), covering the most exposed maritime slopes in the sun. Instead, ivy (Ivy helix), Polipodio vulgare (Polypodiumvulgare), and Sassifraga spatolata (Saxifragacochlearis) are present on the more humid and shaded rocks.

(2) Shrubs, covering maritime slopes, including broom (Spartiumjunceum), spiny broom (Calycotomespinosa), Cisto female (Cistus salvifolius), thyme (Thymus vulgaris), and Euphorbia arborea (Euphorbia dendroides).

(3) Grassland, dominated by Ampelodesmos mauritanicus. 
(4) Evergreen species, such as myrtle (Myrtuscommunis), lentisco (Pistacialentiscus), alaterno (Rhamnusalaternus), terebinth (Pistaciaterebinthus), fillirea (Phillyrealatifolia), strawberry tree (Arbutus unedo), and madder (Rubia peregrine).

(5) Pine grove, covering the Portofino promontory. Three main species can be found. In particular, domestic pine (Pinuspinea), maritime pine (Pinuspinaster), and pinewood (Pinushalepensis).

(6) Holm oak (Quercus ilex) wood.

(7) Chestnut (Castanea sativa) wood.

(8) Mixed mesophilic forest, covering the north-oriented slopes. Its main species are black hornbeam (Ostryacarpinifolia) combined with chestnut (Castanea sativa), laburnum (Laburnum anagyroides), and other trees.

(9) Riparian vegetation on the stream banks and near springs (e.g., Valle dei Mulini area). Among the species are black elderberry (Sambucusnigra), black alder (Alnusglutinosa), and numerous ferns.

Also, a significant variety of animals live in this area. The most common representatives of the local fauna are insects and amphibians. Among the others are the nymph of the strawberry tree (Charaxesjasius), being a typical Mediterranean butterfly, and the stag beetle (Lucanuscervus). Among the amphibians, the reported ones are the spectacled salamander (Salamandrinaperspicillata), two varieties of frogs (Hyla meridionalis and Italian stream frog-Rana italica), and one variety of newt (Speleomantes strinatii). Naturalists have identified more than 100 bird species, including the peregrine falcon (Falco peregrinus). The rugged and unspoiled nature of the park has allowed the adaptation of other birds such as the kestrel, the buzzard, the hallow, the owl, and the barn owl. The most important mammals for naturalists are the small ones (micro-mammals), such as the Etruscan Mustiolo (Suncus etruscus), as well as some species of bats. Among the larger mammals are fox and marten, squirrel, wild boar, and goats.

\section{Hydro-Meteorological Hazards and Vulnerability}

\subsection{Natural Hazards in the Portofino Promontory}

A natural hazard is one of the components that contribute to the definition of risk induced by hydro-meteorological events. A hazard can be defined as the probability that a natural phenomenon (e.g., floods or a landslide) may occur in a certain area with a given return period [29]. Elements at risk include the population, structures, infrastructure, and socio-economic aspects [30-33]. The vulnerability represents the degree of loss of elements exposed to risk, because of the occurrence of a natural phenomenon of a given intensity. The risk corresponds to the expected value of the loss and can be expressed as the product of three terms: hazard, vulnerability, and value of the elements exposed to risk [34].

The more intense meteorological phenomena in Liguria are tied to the so-called depression of the Genoa Gulf ("Genoa Low") [35]. The low pressure is generated by the inflow, into the Mediterranean Sea, of North Atlantic moist air through the Rhone Valley. Cold and humid air enters the Mediterranean, affecting the high mountains of northwestern Corsica, which diverts the current to the northeast, triggering a response of fresh and humid southwestern air, which returns to the Ligurian Gulf, where it affects the mountain ridge located in the immediate vicinity of the sea. A complex interaction is established with the orographic contexts of Liguria. Also, the contrast between the mass of cold and damp air and the warmer water of the Ligurian Sea generates a low-pressure area on the Ligurian Sea, right near Genoa. The depression produces rainfall, often very intense, accompanied by wind and sea storm surges.

The Portofino Promontory is historically also affected by geo-hydrological events, which can produce natural instability processes related to the interaction between meteorological phenomena and the geological environment, thus potentially impacting those elements at risk. The most frequent categories of processes are (1) shallow landslides and flash floods, (2) sea storm surges, and (3) rockfalls 
and mud-debris flows. Often, different processes occur simultaneously during a violent meteorological event, causing a domino effect.

The vulnerable elements along the Ligurian Tyrrhenian coast include those of the Portofino Promontory, which can suffer serious damage, sometimes even with the loss of human lives [36]. Table 2 shows the main geo-hydrological events recorded from 1910 to 2019 in three municipalities of the Portofino Natural Regional Park, based on the severity of the effects on the ground, understood as the intensity of the surveyed damage. Often, the recorded events involved the sum of several interconnected processes, such as shallow landslides and flash floods, or windstorms and rockfalls. Figure 4 shows the number of events per year and the cumulative curve of the area of the Portofino Promontory. The average, on a historical basis, is greater than one event every two years. We can observe an increase in the frequency of phenomena, at least in terms of ground effects, over the last 30 years.

Table 2. Main geo-hydrological events on Portofino Promontory. Municipalities: SML, Santa Margherita Ligure; CAM, Camogli; POR, Portofino.

\begin{tabular}{cccc}
\hline DD/MM/YYYY & Type & Municipality & References \\
\hline $24 / 10 / 1911$ & Flood, Landslide & SML, CAM & {$[37,38]$} \\
$20 / 01 / 1913$ & Landslide & SML, CAM & {$[37]$} \\
$25 / 09 / 1915$ & Flood, Landslide, debris flow & SML, CAM, POR & {$[13,14,37,39]$} \\
$15 / 10 / 1953$ & Flood & SML & {$[37,40]$} \\
$18 / 11 / 1959$ & Flood & SML & {$[37,40]$} \\
$06 / 09 / 1961$ & Flood & SML & {$[22,40]$} \\
$28 / 10 / 1961$ & Flood & SML & {$[22,37,40]$} \\
$01 / 12 / 1961$ & Landslides & CAM & {$[22,41]$} \\
$18 / 04 / 1963$ & Landslides & CAM & {$[22,41]$} \\
$04 / 12 / 1963$ & Flood & SML & {$[37,40]$} \\
$30 / 03 / 1964$ & Debris flow & CAM & {$[22,41]$} \\
$14 / 10 / 1964$ & Debris flow & SML & {$[37]$} \\
$16 / 10 / 1987$ & Landslide & SML & {$[37]$} \\
$26 / 02 / 1989$ & Sea Storm & CAM & {$[42,43]$} \\
$27 / 09 / 1992$ & Flood, Debris flow & CAM, SML & {$[37]$} \\
$15 / 12 / 1993$ & Sea storm & CAM & {$[42,43]$} \\
$04 / 11 / 1994$ & Landslides & CAM, SML & {$[37]$} \\
$04-05 / 10 / 1995$ & Flood, Debris flow & SML, POR, CAM & {$[22,37]$} \\
$25 / 01 / 1996$ & Debris flow & SML, POR, CAM & {$[22,37]$} \\
$06 / 11 / 2000$ & Sea Storm, Debris flow & POR, CAM, SML & {$[22,37,42,43]$} \\
$24 / 11 / 2002$ & Debris flow & CAM & {$[23,37]$} \\
$26 / 01 / 2009$ & Landslide & POR & {$[44]$} \\
$01 / 01 / 2010$ & Sea Storm & CAM & {$[43]$} \\
$24 / 07 / 2014$ & Mudflow & CAM & {$[44]$} \\
$14 / 10 / 2016$ & Downburst & POR, SML & {$[45]$} \\
$25 / 10 / 2016$ & Landslides & CAM & {$[44]$} \\
$29 / 10 / 2018$ & Sea Storm & & {$[46]$} \\
\hline & & &
\end{tabular}

The occurrence of landslides in this area is rather widespread and frequent. These are large relict landslides with slow kinematics [22,26]. Among the latter, rockfall and rock-topple-like phenomena in the conglomerate can become particularly destructive (e.g., the landslides of 1987 [37,44], which required repeated consolidations of the slope).

Rapid mud-debris flows, triggered by heavy rainfalls, are also recurrent and widespread processes in the Portofino Promontory. The events that occurred in 1961, 1963, and 1964 were particularly severe, involving the marly limestone flysch substratum along the western slope $[15,41]$. In more recent times, mud flow phenomena occurred in Santa Margherita in 1996 and Camogli in 2002 [13,26]. 


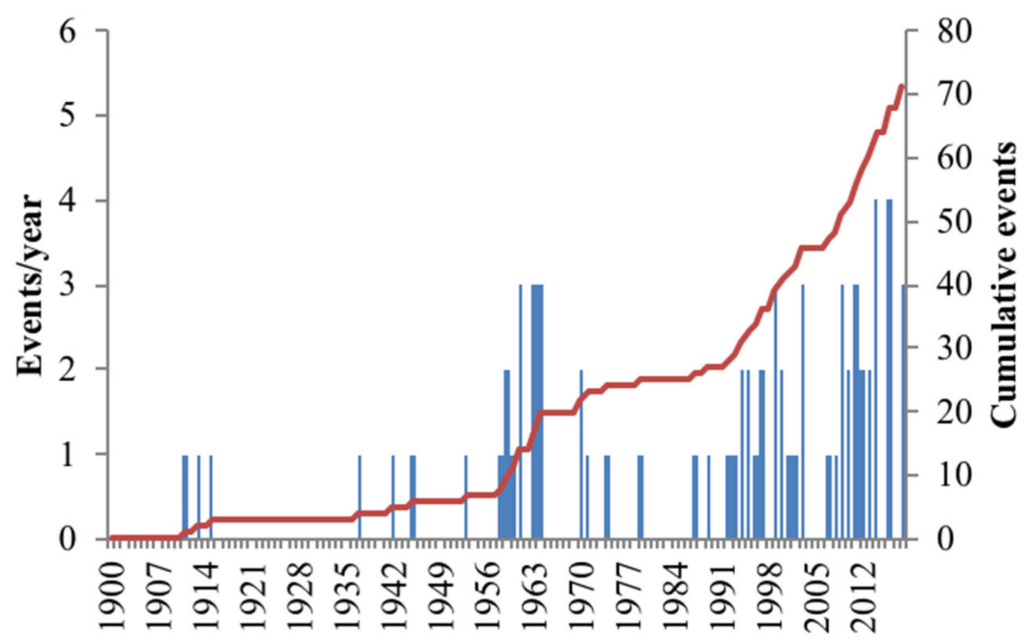

Figure 4. Distribution of geo-hydrological events recorded from 1900 to 2019 in the Portofino Promontory, shown per year and as a cumulative curve.

Finally, recurrent marine weather phenomena, such as sea storm surges and downbursts, are particularly prominent in the western region of the Portofino Promontory due to the exposure of the coast to winds ("Libeccio"). Particularly destructive storms occurred in 1989, 1993, 1999, 2008, and 2010 in Camogli, while in the eastern region, exposed to the Libeccio swell, the most destructive storms occurred in November 2000 and October 2018, which resulted in serious damage to the nearby infrastructure.

A phenomenon attributable to a "downburst" occurred on 14 October 2016, when a low-pressure convective structure formed at the Gulf of Tigullio triggered wind gusts between 100 and $120 \mathrm{~km} / \mathrm{h}$ (hurricane on the Beaufort Scale) near the coast, causing damage to buildings and infrastructure, as well as injuries to the surrounding population.

\subsection{Selected Locations and Hazards for the RECONECT Project}

The European Horizon 2020 RECONECT project includes the design, implementation, monitoring, and evaluation of NBS for geo-hydrological risk reduction within the Portofino Natural Regional Park in the areas of the San Fruttuoso and Paraggi basins. These locations were selected for several reasons:

(1) They are shaped in conglomerate, with large areas of rocky outcrops, both along the coast (from cliffs) and on the slope (from landslides), from which phenomena like rockfall and rock-topple occur systematically.

(2) These basins have a small area, less than $1 \mathrm{~km}^{2}$, with steep slopes, which often leads to frequent flash floods and hyper-concentrated flows.

(3) The drainage network, in addition to the steep slopes, is often filled with debris and wood cover, which enhances the frequency of debris and mud flow events, as well as the transport of solids.

(4) They show anthropic morphologies, with terraces supported by dry stone walls, built in historical times, which nowadays are largely abandoned.

(5) Significant elements at risk are located at the mouth of the streams, both with high cultural (e.g., the Medieval Abbey of San Fruttuoso) and landscape values (Paraggi). These elements are frequently visited by tourists and, as such, they represent an important source of income in the area. For example, the transit of people along the provincial road n. 227 in Paraggi exceeds 1 million people/year, while the village of San Fruttuoso is, on average, visited by 400,000 people/year (Figure 2B).

(6) The reduced hydraulic capacity of the rivers makes them insufficient to transport the flows safely.

(7) Several areas are highly vulnerable. For example, the villages of San Fruttuoso and Paraggi, which have already suffered repeated damage from geo-hydrological events in the last century.

A recent serious event occurred between 27 and 30 October 2018, when, after intense cyclogenesis due to the collision of different air masses, intense precipitation occurred $(100 \mathrm{~mm} / 24 \mathrm{~h})$. During the 
same event, there were also sustained winds that exceeded $120 \mathrm{~km} / \mathrm{h}$. A storm surge of 5-6 m was recorded and it caused serious damage along the coast between Santa Margherita Ligure and Camogli, including the bays of Paraggi and San Fruttuoso (Figure 5a). This event can be compared to those events that occurred in November 2000 (Figure 5e), October 2016 (Figure 5d), and October 2008 [42,43].
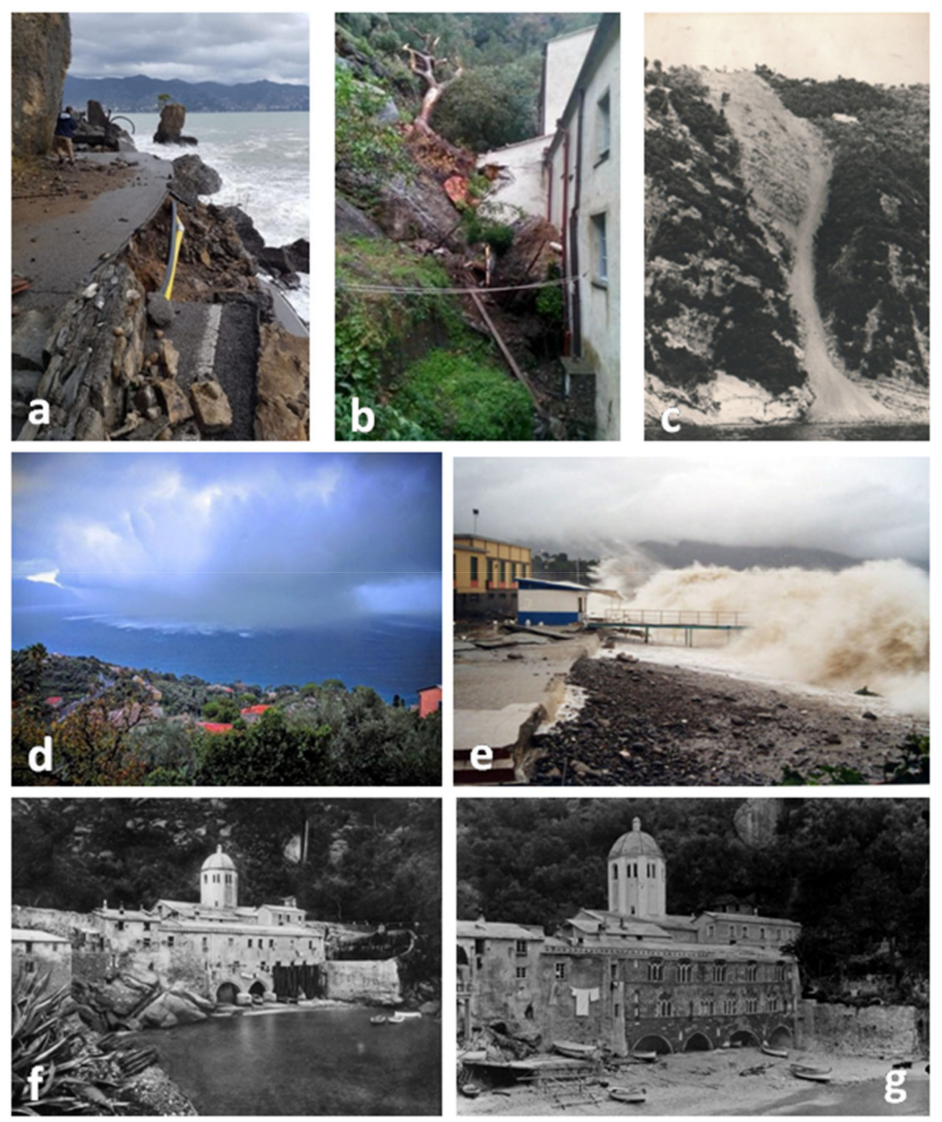

Figure 5. Examples of hydro-meteorological events that occurred in the period from 1900 to the present day: (a) October 2018 storm surge along the coastline between Portofino and Santa Margherita Ligure; (b) rockfall at San Fruttuoso (October 2016 event); (c) debris flow along San Rocco in March 1964; (d) downburst event in October 2016; (e) storm surge along Santa Margherita Ligure beach in November 2000; (f) San Fruttuoso Abbey coastline at the end of the 19th Century; (g) San Fruttuoso Abbey coastline after the event that took place in September 1915.

One of the most powerful geo-hydrological events that occurred in the two case study areas was the event that occurred on 25 September 1915 (Figure 5f,g) [13,39]. The intense rainfall (>400 mm/3 h in Santa Margherita Ligure) triggered a debris-mud flow in the San Fruttuoso basin and formed a beach in front of the Abbey, which was partially destroyed by this event. Significant damage was also recorded in the bay of Paraggi due to the overflowing and erosive activity of the streams. Similar events occurred in March 1964 (Figure 5c) and July 2014 in San Fruttuoso, when peak rainfall exceeded $120 \mathrm{~mm} / 2 \mathrm{~h}$, causing the collapse of some terraces and the consequent flow of mud along the Vallone di San Fruttuoso. This also caused considerable damage to accommodation facilities in the middle of the bathing season.

Rockfall and rock-topple events are frequent in both case study areas, especially in conjunction with hydro-meteorological events, as happened repeatedly in October 2016 in San Fruttuoso, bringing significant damage to buildings (Figure 5b), as well as in January 2009 and September 2012 in Paraggi, when large blocks of conglomerate fell in the square behind the inhabited area on the covered stretch of the Rio dell'Acqua Viva (Figure 5). Detailed analyses of hazards and vulnerabilities in the pilot of the RECONECT Project were examined and presented in a GIS environment (see Figures 6 and 7). 

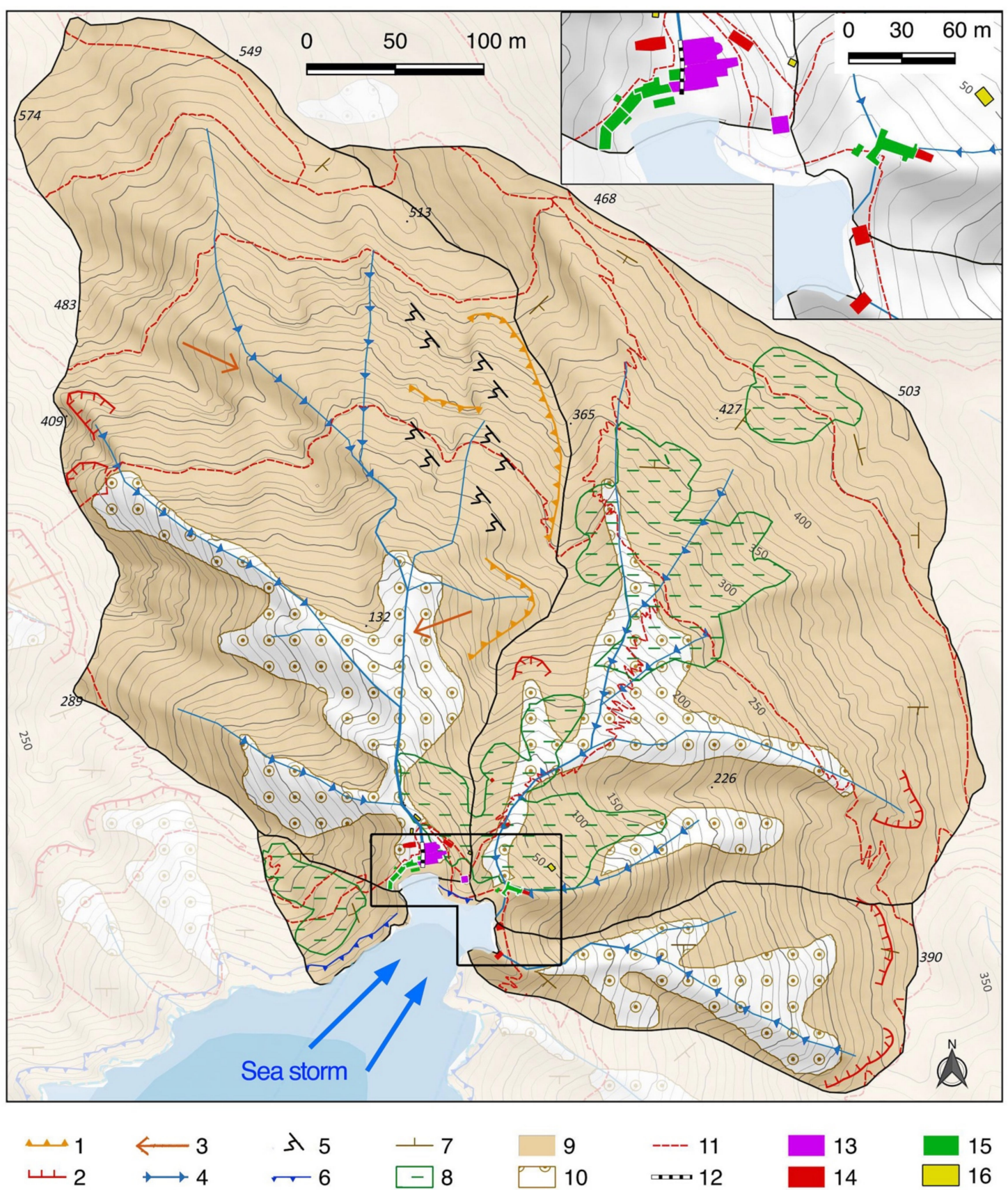

Figure 6. A GIS map of hazards and vulnerabilities in the San Fruttuoso catchment. Legend: (1) Dormant landslide scarp; (2) degradation scarp; (3) slope instability and flow directions; (4) downcutting talweg; (5) slope erosion; (6) cliff; (7) bedding; (8) terraces; (9) conglomerates with sandstone layers; (10) debris cover; (11) trail; (12) culvert; (13) religious building; (14) residential building; (15) receptive building; (16) agricultural/rural building. 


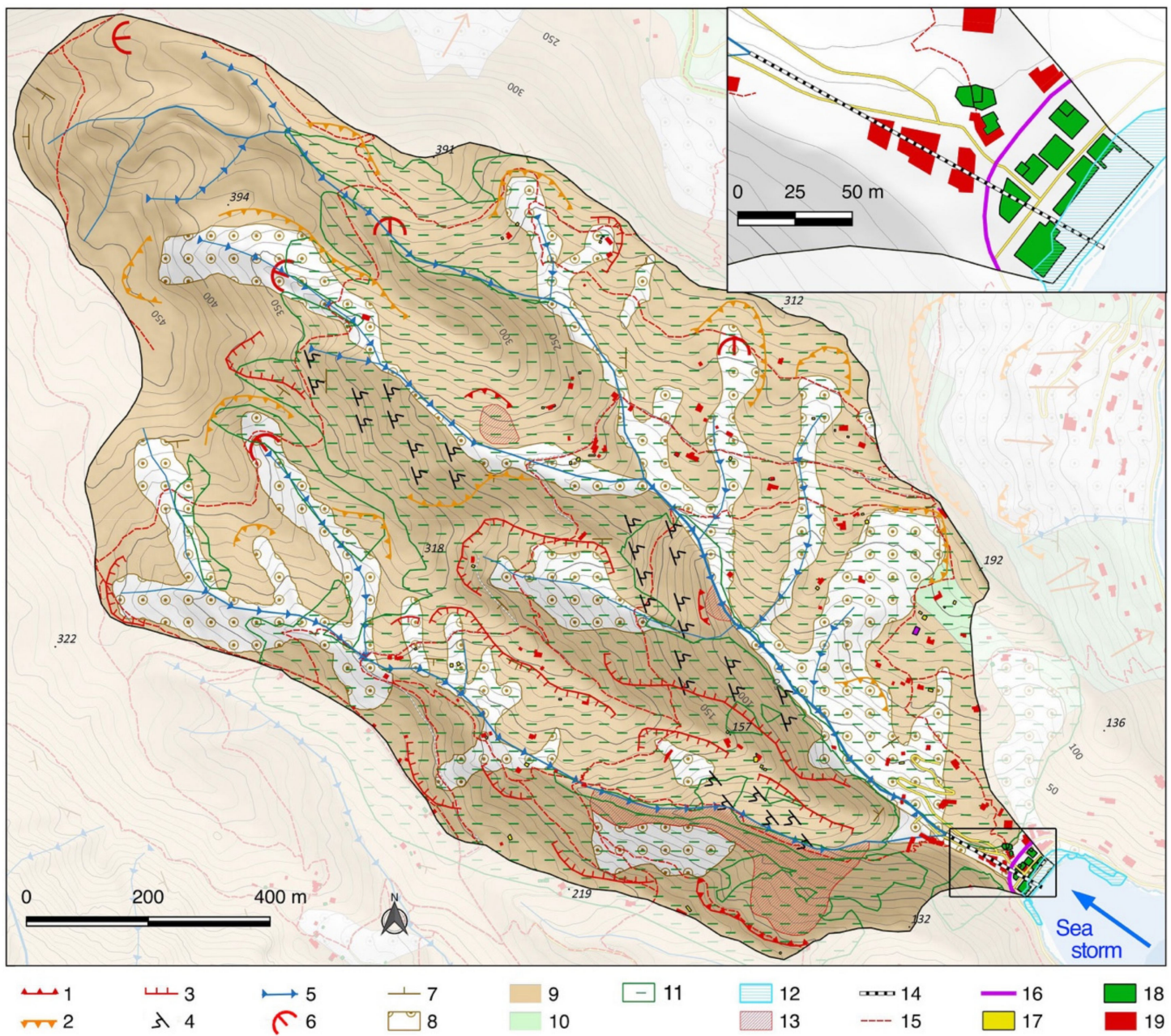

Figure 7. A GIS map of hazards and vulnerabilities in the Paraggi catchment. Legend: (1) Active landslide scarp; (2) dormant landslide scarp; (3) degradation scarp; (4) slope erosion; (5) downcutting talweg; (6) unmappable landslide; (7) bedding; (8) debris cover; (9) conglomerates with sandstone layers; (10) marly limestones, clayed marls, and marls; (11) terraces; (12) marine flood with a return time of 50 years; (13) landslides; (14) culvert; (15) trail; (16) road; (17) agricultural/rural building; (18) receptive building; (19) residential building.

\section{Selection of Nature-Based Solutions}

\subsection{Foreseen Solutions in the Case Study Area of the Portofino Natural Regional Park}

Among all of the possible interventions that can be implemented in the protected area, NBS are considered as the most suitable ones due to their minimal impact and the possibilities for integration with the natural environment. The Portofino Natural Regional Park has already been promoting interventions aimed at reducing geo-hazards and vulnerability of the protected area, as well as of the surrounding urban areas, against climate changes and extreme rainfall events. As part of the RECONECT project, and to achieve sound engineering and technological solutions that can also preserve unique landscapes with natural, cultural heritage, and economic values of the area, the Park authorities will implement a set of NBS in the areas of San Fruttuoso and Paraggi. The purpose of the work is to demonstrate how NBS can be integrated into such areas and how to reduce the hydro-meteorological risk for given climate change scenarios.

The main benefit of NBS in San Fruttuoso is to address the following challenges: stabilization of rock masses; reduction of geo-hydrologic risks in order to intercept and reduce the floating and solid transport along the rivers and to reduce erosion; wood amelioration, by removing allochthones and 
degraded species of old conifers (Pinus pinea L. and P. halepensis Mill.), which suffer in a Mediterranean environment and have low adaptation to climate change, to favor the natural regeneration of holms (Quercus ilex L.), the climax species in the area; construction of dry stone walls and restoration of abandoned terraces, with the aim to valorize the terraced landscape and promote agricultural activities.

The reconstruction of terraces and the regeneration of natural and man-made ecosystems will also be implemented in the Paraggi basin. In addition, hydraulic-forestry arrangements on water courses will be undertaken to improve the outflow and decrease floating and solid transport (e.g., removal of trees and dead vegetation from the river bed). Furthermore, other measures such as riverbed and tributary arrangements (e.g., construction of wooden weirs made by wood and stones that can raise the riverbed level and enable settling of sediments), maintenance along hiking paths, slope stabilization, and cleaning and removing dead vegetation and dirt will be also done. Figures 8 and 9 (A, B, ... sites) depict areas where different sets of interventions will be carried out within the RECONECT project.

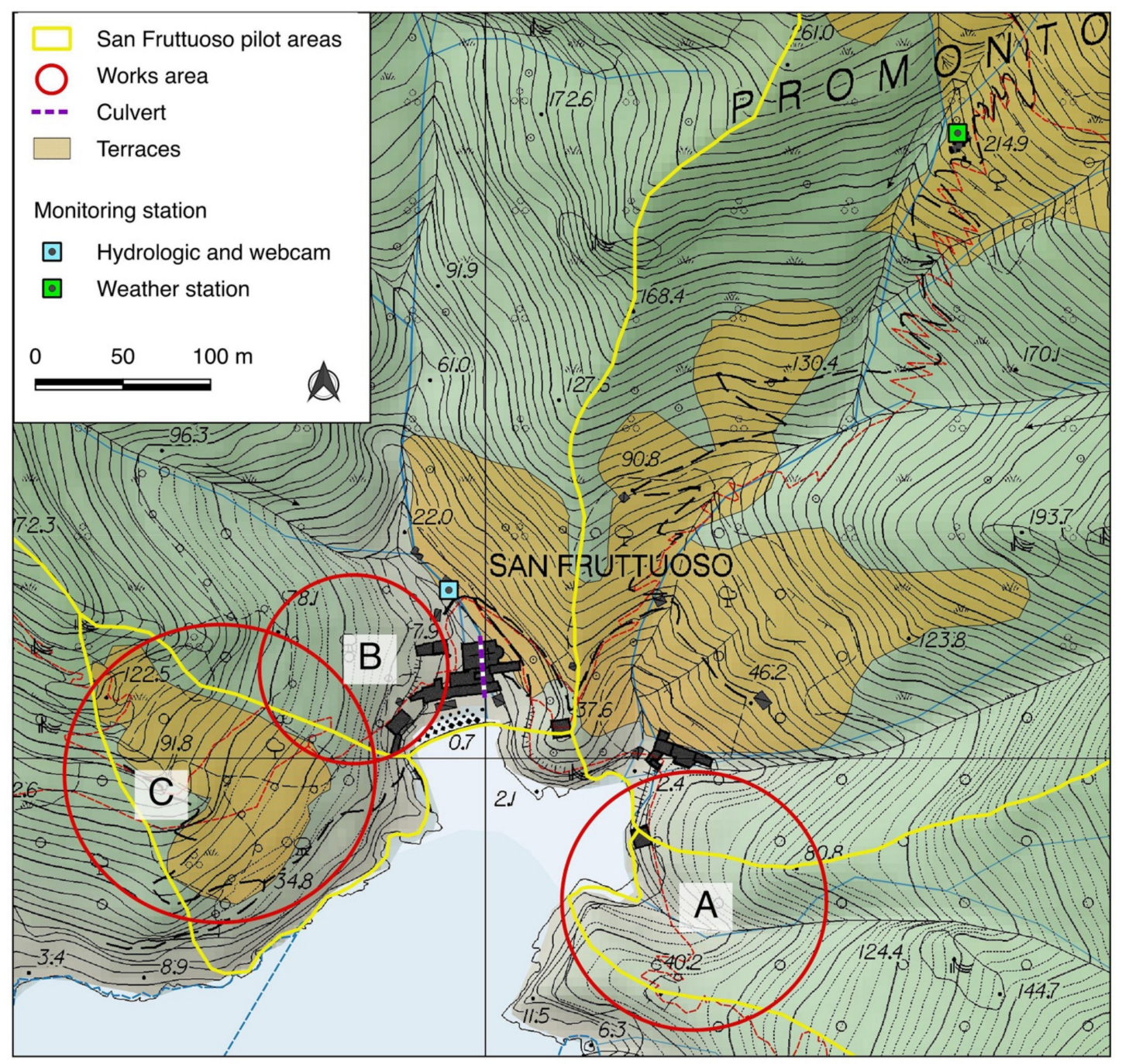

Figure 8. A GIS map of the San Fruttuoso area depicting risk reduction interventions with NBS and monitoring systems. Red circles highlight the critical areas which have been selected as high priority areas, and capital letters A, B, and C refer to the scope of work described in Section 4.1

It is interesting to observe that forests in the Portofino Natural Regional Park also provide a unique combination of environmental and landscape features with multiple functions, such as that of an ecological, recreational, or hydro-meteorological nature. 


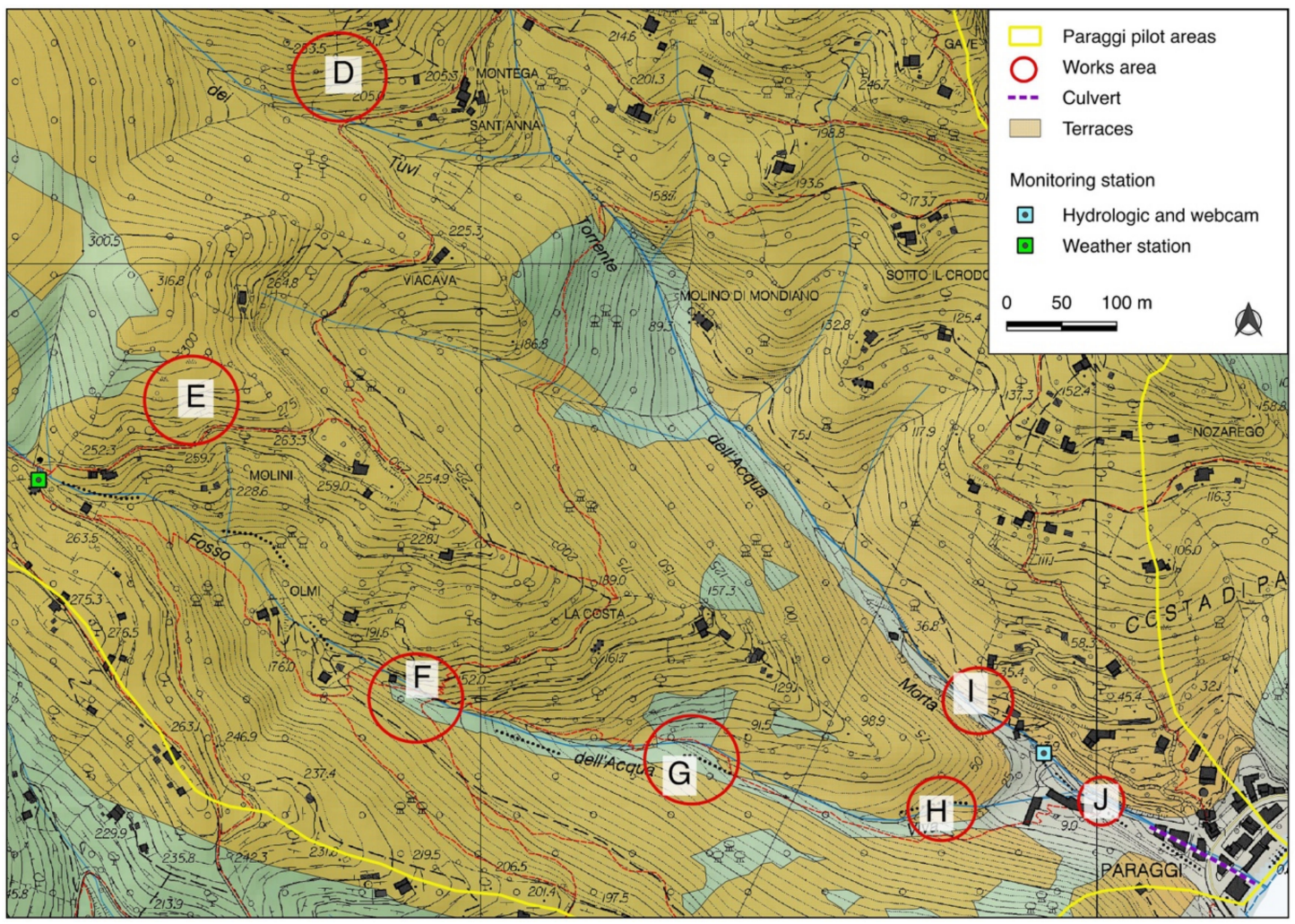

Figure 9. A GIS map of the Parragi area depicting risk reduction interventions with NBS and monitoring systems. Red circles highlight the critical areas which have been selected as high priority areas, and capital letters D-J refer to the scope of work described in Section 4.1.

\subsection{Hydro-Meteorological Monitoring Activities}

The existing hydro-meteorological datasets have been compiled and made available by the Portofino Natural Regional Park Authority and Liguria Information Systems. They include both geospatial and environmental information, with implementation within a specific monitoring program. In particular, the RECONECT project foresaw the selection, installation, and operation of hydro-meteorological instruments that will include three weather stations, two hydrometers, and two cameras. The technical specifications, data formats, and data platform characteristics are currently under definition. The necessary equipment will be bought and installed once the selection of indicators for the evaluation of NBS is complete. Monitoring activities also include remote sensing activities such as LIDAR surveys, orthophotography, and infrared aerial photography. These surveys are scheduled for the first quarter of 2020 when the vegetation cover is minimal. From these data sets, the project team will be able to assess the characteristics of morphological features, identify areas prone to mud-debris flows, and estimate hydro-meteorological risks. These assessments will be cross-referenced and compared with other RECONECT sites that have similar morphological features.

\subsection{NBS Performance Indicators}

The RECONECT project team has identified key variables and indicators that need to be monitored and assessed in all NBS demonstration sites. These indicators will form a basis for evaluation and cross-referencing NBS performance in all sites. The RECONECT indicators are divided into three categories: water, nature, and people (see Table 3). Table 3 presents the list of variables and performance indicators, selected from the original performance indicator table, to be monitored in the Portofino Natural Regional Park. 
Table 3. RECONECT project key performance indicators (KPIs) to be monitored in the Portofino Natural Regional Park area. Please note that "Monitoring phase (number of checks)" represents pre- (1) and post-NBS implementation (2) monitoring.

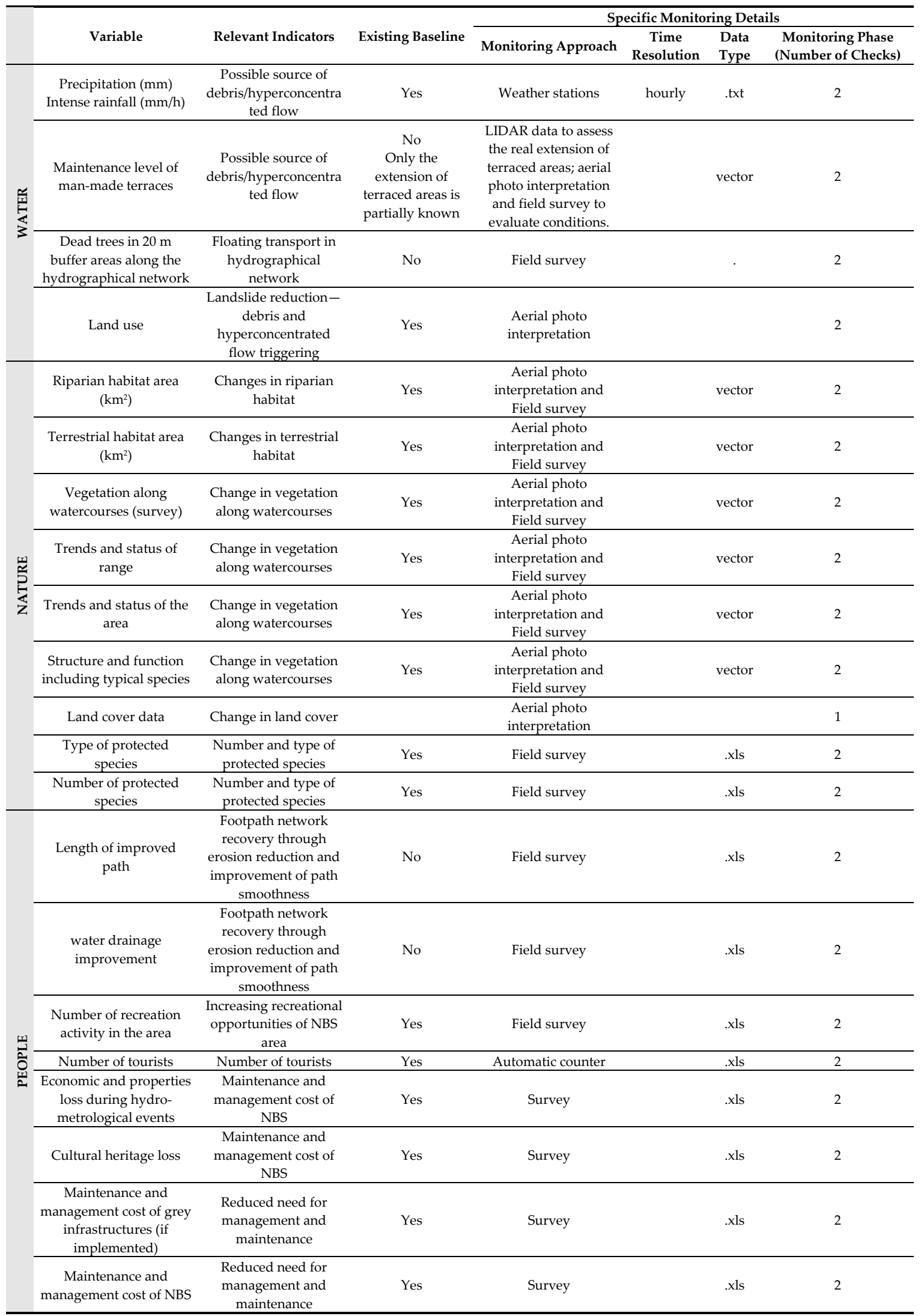


The assessment of the impacts of hydro-meteorological events will address aspects such as society, built environment, park-generated ecosystem services, and biodiversity. For this purpose, the project team will apply a variety of methods-see, for example, $[5,10,47,48]$. The ecosystem services will be classified and quantified by applying a non-monetary donor-side approach based on emergy accounting (see, for example, [49,50]). The emergy method, which was proposed and developed by the system ecologist H.T. Odum and his followers, enables researchers to quantify the cumulative available energy involved, both directly and indirectly, to make a product or service [51]. In particular, resources in all forms (e.g., energy, materials, labor, economic services, and information) are quantified by applying a common metrological reference, referred to as solar equivalent energy (measured in sej units [51]). Furthermore, the impacts of natural hazards on ecosystems can be quantified by applying the same metrics [52-54]. In this way, disordering events, such as natural hazards, can be described in emergy terms as "emergy inputs". This approach will form part of the RECONECT's holistic ecosystem-based framework, which aims to apply multi-faceted and transdisciplinary assessment of NBS in the context of hydro-meteorological risk reduction. A discussion concerning the evaluation criteria is beyond the scope of the present paper but will be developed and discussed in our future papers.

\section{Discussion}

The joint monitoring and evaluation of NBS is a process that combines the collection of heterogeneous data and analysis, for which some results can be obtained in a relatively short period of time (e.g., assessment of certain rainfall-runoff processes), while some other results can only be obtained after longer periods (e.g., repopulation of Mediterranean high trunk plant species and reintroduction of some faunal species). Hence, the overall monitoring campaign needs to be planned in relation to the different spatial and temporal scales required for different indicators.

Once the first evaluation results become available, the potential for upscaling different NBS for different contexts will be assessed. In terms of the results from the Portofino Natural Regional Park, these findings could be particularly relevant for those areas that fit the context of the Mediterranean region. This relevance does not only apply to the elements that need to be protected (e.g., areas of high natural value, areas with cultural heritage sites), which also applies to the morphological conditions of the basins (e.g., areas with steep slopes, areas with similar lithological and structural conditions) and geo-hydrological hazards driven by hydro-meteorological events that are difficult to predict at the local scale. Further to this, the foreseen effects of climate change on weather extremes in the Mediterranean should be considered, including a variation in sea storms, variability of storm surge extremes, severe rainfalls, and prolonged desiccation events [54-59]. In particular, special attention should be given to the analysis of high-intensity rainfall events, which have caused many flash floods, landslides, and debris and hyper-concentrated flows in the Liguria region (see Figures 3 and 5f,g).

The efficiency of NBS implementation will be carefully measured and monitored with real-time sensors and SCADA systems, which will, in turn, provide effective on-line and off-line communication to the decision-enhancing facilities of the RECONECT monitoring and evaluation platform. Several innovative monitoring technologies and methods will be applied for the assessment of the effectiveness of NBS. For example, the use of unmanned aerial vehicles as proximal sensing platforms will be used to address multi-scale and multi-parameter representations of the environment and to generate augmented information for management and planning purposes [60-63]. Meanwhile, the partial and limited nature of any individual case study can be overcome by considering the wide geographical distribution of all case studies. Consequently, any impacts of NBS on the preservation of a wider set of ecosystem services, available under different environmental conditions, can be estimated. In this respect, the wide application of energy accounting, based on a holistic approach already applied in several contexts to generate policies and planning solutions, could be extended to other project sites outside of the Portofino area. The Portofino demonstration case study is of special interest; in fact, although being inserted in an anthropized context, it is a site of interest for the protection of biodiversity and for the existing ecosystem services it provides. Consequently, this is an additional 
benefit compared to the implementation of NBS to protect the population, the built environment, and/or cultural heritage. This approach makes the Portofino Natural Regional Park part of the national and international institutions that are adopting and promoting holistic approaches with integrated NBS and IT solutions to manage climate change impacts.

Several benefits and co-benefits are expected to be obtained from the Portofino NBS demonstration case: (1) Decrease of geo-hydrological vulnerability for the main infrastructures and the cultural heritage; (2) re-building/maintenance of dry stone walls, which will contribute to the restoration of old terraces and will re-incentivize agricultural activities with benefits for the landscape (terraces are part of the landscape and cultural heritage), as well as for geo-hydrological risk mitigation-in this respect, an analysis of geomorphological, geological, historical, and socio-economic factors has clearly shown that the abandonment of terraces led to an increase in geo-hydrological risk in an area already struggling to maintain a delicate balance between natural and historical aspects of its landscape [64-67]; (3) decrease of the impacts by landslides and slope instability at the coastal sediment amount level [68]; (4) decrease of the risk of injuries among the park visitors due to slope instability of interesting hiking paths during heavy rainfalls; (5) support for the interaction between private landowners; (6) integration of the proposed NBS with regional policies for land management/planning and with the Basin Master Plan [69,70]; (7) improvement of the visibility and governance model of the Portofino Natural Regional Park, also in the perspective of becoming a National Park; and (8) improvement of the collaboration between the park authority and the stakeholders.

\section{Conclusions}

Over the past three decades, damages caused by hydro-meteorological events have increased rapidly when compared to any other type of natural disaster. The discrepancy between the implementation of technological approaches in response to natural disasters has revealed the need to rethink our way of looking at such disasters. It is now clear that new solutions need to be more in harmony with nature in order to become more sustainable and more effective in protecting societies, built environments, cultural heritage, ecosystem services, and biodiversity. Also, challenges due to climate change, population growth, and urban expansion are placing additional pressure on natural resources that, consequently, are drastically decreasing. An urban development that integrates green infrastructures or nature-based solutions into planning practices has a great potential to make urban and surrounding rural areas more resilient and adaptive to hydro-meteorological events. NBS can also provide a wealth of social, environmental, and economic benefits (or co-benefits) with valid conceptual strength to address a range of challenges in a holistic manner. Hence the importance of NBS implementation and evaluation work in the Portofino Natural Regional Park within the RECONECT project.

The evidence base that will be generated within the RECONECT project will serve in the development of guidelines and policies related to the application of NBS in different climatological and social contexts. The development of key performance indicators (KPIs) will be used as a basis for monitoring and evaluating NBS projects. In particular, findings from the Portofino Natural Regional Park will be used for upscaling NBS in Mediterranean areas, from the French Riviera to the Balearic Islands, to Campania, Sicily, and Calabria in Italy, and, further, to the Greek Islands and their coastlines. This information will be beneficial for small mountainous catchments that have similar geo-hydrological hazards.

For the Portofino Natural Regional Park, the necessity for implementing NBS sites is now very obvious and highly desirable. However, despite the growing evidence of benefits from NBS sites, there are still many cases in which land use planning and management policies, combined with various limiting financial mechanisms, tend to ignore these possibilities, for which we hope that our work will provide a valuable source of inspiration.

Author Contributions: Conceptualization, G.P.; methodology, L.T. and M.C.; validation, F.L., F.F., and G.P.; investigation, F.F. and G.P.; resources, L.T.; data curation, M.C. and L.T.; writing一original draft preparation, L.T., 
F.F., and M.C.; writing—review and editing, A.M., Z.V., and F.L.; supervision, Z.V.; project administration, L.T.; funding acquisition, F.F. and F.L. All authors read and agreed to the published version of the manuscript.

Funding: This article is an outcome of the RECONECT project (Regenerating ECOsystems with Nature-based solutions for hydro-meteorological risk rEduCTion). This project received funding from the European Union's Horizon 2020 Research and Innovation Program under grant agreement No 776866.

Acknowledgments: The authors wish to thank Riccardo Buelli, Alessandro Capretti and Benedetto Mortola for the support, the data provided and the historical pictures of San Fruttuoso. A special thanks goes to the anonymous reviewers for the improvement of the text.

Conflicts of Interest: The authors declare no conflicts of interest.

\section{References}

1. Raymond, C.M.; Frantzeskaki, N.; Kabisch, N.; Berry, P.; Breil, M.; Razvan Nita, M.; Geneletti, D.; Calfapietra, C. A framework for assessing and implementing the co-benefits of nature-based solutions in urban areas. Environ. Sci. Policy 2017, 77, 15-24. [CrossRef]

2. Ruangpan, L.; Vojinovic, Z.; Di Sabatino, S.; Leo, L.S.; Capobianco, V.; Oen, A.M.P.; McClain, M.; Lopez-Gunn, E. Nature-Based Solutions for hydro-meteorological risk reduction: A state-of-the-art review of the research area. Nat. Hazards Earth Syst. Sci. 2019. [CrossRef]

3. Kabisch, N.; Korn, H.; Stadler, J.; Bonn, A. Nature-Based Solutions to Climate Change Adaptation in Urban Areas; Springer: Cham, Switzerland, 2016. [CrossRef]

4. Zedler, J.B. Wetlands at your service: Reducing impacts of agriculture at the watershed scale. Front. Ecol. Environ. 2003. [CrossRef]

5. Vojinovic, Z.; Hammond, M.; Golub, D.; Hirunsalee, S.; Weesakul, S.; Meesuk, V.; Medina, N.; Sanchez, A.; Kumara, S.; Abbott, M. Holistic approach to flood risk assessment in areas with cultural heritage: A practical application in Ayutthaya, Thailand. Nat. Hazards 2016, 81, 589-616. [CrossRef]

6. Boukalova, Z.; Tesitel, J.; Das Gurung, B. Constructed wetlands and their implementation on private and public land in Kathmandu valley, Nepal. Ecol. Environ. 2019, 229, 1-8.

7. Klijn, F.; Asselman, N.; Wagenaar, D. Room for Rivers: Risk Reduction by Enhancing the Flood Conveyance Capacity of The Netherlands' Large Rivers. Geosciences 2018, 8, 224. [CrossRef]

8. Warner, J.F.; van Buuren, M.W. Implementing Room for the River: Narratives of success and failure in Kampen, The Netherlands. Int. Rev. Adm. Sci. 2011, 77, 779-802. [CrossRef]

9. Chun, R.J. Achieving Successful River Restoration in Dense Urban Areas: Lessons from Taiwan. Sustainability 2016, 8, 1159. [CrossRef]

10. PHUSICOS EU Project. Available online: https://phusicos.eu/ (accessed on 13 November 2019).

11. OPERANDUM EU Project. Available online: https://www.operandum-project.eu/ (accessed on 13 November 2019).

12. Strahler, A.N. Physical Geography. Visual Aids Manual; John Wiley \& Sons: New York, NY, USA, 1951; Volume 32, p. 13.

13. Faccini, F.; Piccazzo, M.; Robbiano, A.; Roccati, A. Applied Geomorphological Map of the Portofino Municipal territory (Italy). J. Maps 2008, 4, 451-462. [CrossRef]

14. Faccini, F.; Gabellieri, N.; Paliaga, G.; Piana, P.; Angelini, S.; Coratza, P. Geoheritage map of the Portofino Natural Park (Italy). J. Maps 2018, 14, 87-96. [CrossRef]

15. Brandolini, P.; Faccini, F.; Piccazzo, M. Geomorphological hazard and tourist vulnerability along Portofino Park trails (Italy). Nat. Hazard Earth Syst. Sci. 2006, 6, 563-571. [CrossRef]

16. Köppen, W. Das Geographische System der Klimate. In Handbuch der Klimatologie; Köppen, W., Geiger, R., Eds.; Gebrüder Borntraeger: Berlin, Germany, 1936; Volume 1, pp. 1-44. (In German)

17. Sacchini, A.; Ferraris, F.; Faccini, F.; Firpo, M. Environmental climatic maps of Liguria. J. Maps 2012, 8, 199-207. [CrossRef]

18. Acquaotta, F.; Faccini, F.; Fratianni, S.; Paliaga, G.; Sacchini, A.; Vilìmek, V. Increased flash flooding in Genoa Metropolitan Area: A combination of climate changes and soil consumption? Meteorol. Atmos. Phys. 2019, 131, 1099-1110. [CrossRef]

19. Giammarino, S.; Messiga, B. Clasti di meta-ofioliti a paragenesi di alta pressione nel Conglomerato di Portofino: Implicazioni paleogeografiche e strutturali. Ofioliti 1979, 4, 25-41. (In Italian) 
20. Corsi, B.; Elter, F.M.; Giammarino, S. Structural fabric of the Antola Unit (Riviera di Levante, Italy) and implications for its alpine versus Apennine origin. Ofioliti 2001, 26, 1-8.

21. Bonaria, V.; Faccini, F.; Galiano, I.C.; Sacchini, A. Hydrogeology of conglomerate fractured-rock aquifers: An example from the Portofino's Promontory (Italy). Rend. Online Soc. Geol. Ital. 2016, 41, 22-25. [CrossRef]

22. Brandolini, P.; Faccini, F.; Robbiano, A.; Terranova, R. Geomorphological hazard and monitoring activity along the western rocky coast of the Portofino Promontory (Italy). Quat. Int. 2007, 171, 131-142. [CrossRef]

23. Tarolli, P.; Preti, F.; Romano, N. Terraced landscapes: From an old best practice to a potential hazard for soil degradation due to land abandonment. Anthropocene 2014, 6, 10-25. [CrossRef]

24. Arnaèz, J.; Lana-Renault, N.; Lasanta, T.; Ruiz Flaño, P.; Castroviejo, J. Effects of farming terraces on hydrological and geomorphological processes. A review. Catena 2015, 128, 122-134. [CrossRef]

25. Galve, J.P.; Cevasco, A.; Brandolini, P.; Soldati, M. Assessment of shallow landslide risk mitigation measures based on land use planning through probabilistic modelling. Landslides 2015, 12, 101-114. [CrossRef]

26. Paliaga, G.; Giostrella, P.; Faccini, F. Terraced Landscape as Cultural and Environmental Heritage at Risk: An Example from Portofino Park (Italy). ANNALES Ser. Hist. Sociol. 2016, 2, 513-522. [CrossRef]

27. Gestro, C. Education to protection of biodiversity in Liguria. Ital. Bot. 2004, 36, 537-539.

28. Balletti, F.; Soppa, S. The landscapes of the Portofino natural regional Park. In Nature Policies and Landscape Policies; Springer: Cham, Switzerland, 2015; pp. 415-422.

29. Kron, W. Flood Risk = Hazard • Values • Vulnerability. Water Inter. 2005, 30, 58-68. [CrossRef]

30. Paliaga, G.; Faccini, F.; Luino, F.; Turconi, L. A spatial multicriteria prioritizing approach for geohydrological risk mitigation planning in small and densely urbanized Mediterranean basins. Nat. Hazards Earth Syst. Sci. 2019, 19, 53-69. [CrossRef]

31. Turconi, L.; Luino, F.; Gussoni, M.; Faccini, F.; Giardino, M.; Casazza, M. Intrinsic Environmental Vulnerability as Shallow Landslide Susceptibility in Environmental Impact Assessment. Sustainability 2019, 11, 6285. [CrossRef]

32. Paliaga, G.; Faccini, F.; Luino, F.; Turconi, L.; Bobrowsky, P. Geomorphic processes and risk related to a large landslide dam in a highly urbanized Mediterranean catchment (Genova, Italy). Geomorphology 2019, 327, 48-61. [CrossRef]

33. Palladino, M.R.; Viero, A.; Turconi, L.; Brunetti, M.T.; Peruccacci, S.; Melillo, M.; Luino, F.; Deganutti, A.M.; Guzzetti, F. Rainfall thresholds for the activation of shallow landslides in the Italian Alps: The role of environmental conditioning factors. Geomorphology 2018, 303, 53-67. [CrossRef]

34. Canuti, P.; Casagli, N.; Pellegrini, M.; Tosatti, G. Geo-hydrological hazards'. Anatomy of an Orogen, the Apennines and adjacent Mediterranean Basins; Vai, G.B., Martini, I.P., Eds.; Kluwer Academic Publisher: Dordrecht, The Netherlands, 2001; pp. 513-532.

35. Trigo, I.F.; Davies, T.D.; Bigg, G.R. Objective climatology of cyclones in the Mediterranean region. J. Clim. 1999, 12, 1685-1696. [CrossRef]

36. Luino, F.; Paliaga, G.; Roccati, A.; Sacchini, A.; Turconi, L.; Faccini, F. Anthropogenic changes in the alluvial plains of the Tyrrhenian Ligurian basins. Rend. Online Soc. Geol. Ital. 2019, 48, 10-16. [CrossRef]

37. The AVI project of CNR-GNDCI. Available online: http://avi.gndci.cnr.it/ (accessed on 25 July 2019).

38. Berri, P. Rapallo nei secoli; Edizioni Ipotesi: Liguria, Italy, 1979.

39. Parodi, A.; Ferraris, L.; Gallus, W.; Maugeri, M.; Molini, L.; Siccardi, F.; Boni, G. Ensemble cloud-resolving modelling of a historic back-building mesoscale convective system over Liguria: The San Fruttuoso case of 1915. Clim. Past. 2017, 13, 455-472. [CrossRef]

40. Ministero dei Lavori Pubblici. Annali Idrologici; Ministero dei Lavori Pubblici: Roma, Italy, $1934-2003$. Available online: http://www.acq.isprambiente.it/annalipdf/ (accessed on 10 August 2019).

41. Terranova, R. Squilibri geomorfologici e rischi sulla costa alta rocciosa occidentale del Promontorio di Portofino (Liguria Orientale). In Studi geografici e geologici in onore di S. Belloni; Università degli Studi di Milano e Milano Bicocca: Milano, Italy, 1999; pp. 595-607. (In Italian)

42. Orlandi, A.; Pasi, F.; Onorato, L.F.; Gallino, S. An observational and numerical case study of a flash sea storm over the Gulf of Genoa. Adv. Sci. Res. 2008, 2, 107-112. [CrossRef]

43. Pasi, F.; Orlandi, A.; Onorato, L.F.; Gallino, S. A study of the 1 and 2 January 2010 sea-storm in the Ligurian Sea. Adv. Sci. Res. 2011, 6, 109. [CrossRef]

44. Il Secolo XIX. Italian National Newspaper. Available online: www.ilsecoloxix.it (accessed on 7 July 2019). 
45. Agenzia Regionale per la Protezione dell'Ambiente Liguria ARPAL. Report 2016. Available online: http: //www.arpal.gov.it/ (accessed on 15 July 2019).

46. Agenzia Regionale per la Protezione dell'Ambiente Liguria ARPAL. Report 2018. Available online: http: //www.arpal.gov.it/ (accessed on 15 July 2019).

47. Alvesa, A.; Gersonius, B.; Kapelan, Z.; Vojinovic, Z.; Sancheza, A. Assessing the Co-Benefits of green-blue-grey infrastructure for sustainable urban flood risk management. J. Environ. Manag. 2019, 239, 244-254. [CrossRef] [PubMed]

48. Goepel, K.D. Implementation of an Online Software Tool for the Analytic Hierarchy Process (AHP-OS). Intern. J. Anal. Hierarchy Process 2018, 10, 469-487. [CrossRef]

49. Yang, Q.; Liu, G.; Casazza, M.; Campbell, E.T.; Giannetti, B.F.; Brown, M.T. Development of a new framework for non-monetary accounting on ecosystem services valuation. Ecosyst. Serv. 2018, 34, 37-54. [CrossRef]

50. Shah, S.M.; Liu, G.; Yang, Q.; Wang, X.; Casazza, M.; Agostinho, F.; Lombardi, G.V.; Giannetti, B.F. Emergy-based Valuation of Agriculture Ecosystem Services and Dis-services. J. Clean. Prod. 2019. [CrossRef]

51. Odum, H.T. Environmental Accounting: Emergy and Environmental Decision Making; John Wiley Sons Inc.: New York, NY, USA, 1996.

52. Brown, M.T. War, Peace, and the Computer: Simulation of Disordering and ordering Energies in South Vietnam. In Ecosystems Modeling: Theory and Practice; Hall, C., Day, J., Eds.; Wiley Interscience: New York, NY, USA, 1976.

53. Prado-Jartar, M.A.; Brown, M.T. Interface Ecosystems with an Oil Spill in a Venezuelan Tropical Savannah. Ecol. Eng. 1996, 8, 49-78. [CrossRef]

54. Bianciardi, C.; Ulgiati, S. Entropy. In Encyclopedia of Energy; Cleveland, C., Ed.; Academic Press: Oxford, UK; Elsevier: Oxford, UK, 2004; pp. 459-470.

55. Androulidakis, Y.S.; Kombiadou, K.D.; Makris, C.V.; Baltikas, V.N.; Krestenitis, Y.N. Storm surges in the Mediterranean Sea: Variability and trends under future climatic conditions. Dyn. Atmos. Oceans 2015, 71, 56-82. [CrossRef]

56. Sanchez-Arcilla, A.; Sierra, J.P.; Brown, S.; Casas-Prat, M.; Nicholls, R.J.; Lionello, P.; Conte, D. A review of potential physical impacts on harbours in the Mediterranean Sea under climate change. Reg. Environ. Chang. 2016, 16, 2471-2484. [CrossRef]

57. Ziv, B.; Harats, N.; Morin, E.; Yair, Y.; Dayan, U. Can severe rain events over the Mediterranean region be detected through simple numerical indices? Nat. Hazards 2016, 83, 1197-1212. [CrossRef]

58. Casazza, M.; Lega, M.; Liu, G.; Ulgiati, S.; Endreny, T.A. Aerosol pollution, including eroded soils, intensifies cloud growth, precipitation, and soil erosion: A review. J. Clean. Prod. 2018, 189, 135-144. [CrossRef]

59. Zamir, R.; Alpert, P.; Rilov, G. Increase in Weather Patterns Generating Extreme Desiccation Events: Implications for Mediterranean Rocky Shore Ecosystems. Estuaries Coasts 2018, 41, 1868-1884. [CrossRef]

60. Gargiulo, F.; Persechino, G.; Lega, M.; Errico, A. IDES project: A new effective tool for safety and security in the environment. In International Conference on Algorithms and Architectures for Parallel Processing; Koodziej, J., Di Martino, B., Talia, D., Xiong, K., Eds.; Springer: Cham, Switzerland, 2013; pp. 201-208.

61. Errico, A.; Angelino, C.V.; Cicala, L.; Persechino, G.; Ferrara, C.; Lega, M.; Vallario, A.; Parente, C.; Masi, G.; Gaetano, R.; et al. Detection of environmental hazards through the feature-based fusion of optical and SAR data: A case study in southern Italy. Int. J. Remote Sens. 2015, 36, 3345-3367. [CrossRef]

62. Lega, M.; Casazza, M.; Teta, R.; Zappa, C.J. Environmental impact assessment: A multi-level, multi-parametric framework for coastal waters. Int. J. Sustain. Dev. Plan. 2018, 13, 1041-1049. [CrossRef]

63. Casazza, M.; Lega, M.; Jannelli, E.; Minutillo, M.; Jaffe, D.; Severino, V.; Ulgiati, S. 3D monitoring and modelling of air quality for sustainable urban port planning: Review and perspectives. J. Clean. Prod. 2019, 231, 1342-1352. [CrossRef]

64. Van Der Sluis, T.; Kizos, T.; Pedroli, B. Landscape change in Mediterranean farmlands: Impacts of land abandonment on cultivation terraces in Portofino (Italy) and Lesvos (Greece). J. Landsc. Ecol. 2014, 7, $23-45$. [CrossRef]

65. Turconi, L.; Nigrelli, G.; Conte, R. Historical datum as a basis for a new GIS application to support civil protection services in NW Italy. Comput. Geosci. 2014, 66, 13-19. [CrossRef]

66. Luino, F.; Nigrelli, G.; Turconi, L.; Faccini, F.; Agnese, C.; Casillo, F. A proper land-use planning through the use of historical research. Disaster Adv. 2016, 9, 8-19. 
67. Kabisch, N.; Frantzeskaki, N.; Pauleit, S.; Naumann, S.; Davis, M.; Artmann, M.; Haase, D.; Knapp, S.; Korn, H.; Stadler, J.; et al. Nature-based solutions to climate change mitigation and adaptation in urban areas: Perspectives on indicators, knowledge gaps, barriers, and opportunities for action. Ecol. Soc. 2016, 21, 39. [CrossRef]

68. Jiménez López, J.; Mulero-Pázmány, M. Drones for Conservation in Protected Areas: Present and Future. Drones 2019, 3, 10. [CrossRef]

69. Ronchi, S.; Arcidiacono, A. Adopting an Ecosystem Services-Based Approach for Flood Resilient Strategies: The Case of Rocinha Favela (Brazil). Sustainability 2019, 11, 4. [CrossRef]

70. Kim, H.W.; Tran, T. An Evaluation of Local Comprehensive Plans Toward Sustainable Green Infrastructure in US. Sustainability 2018, 10, 4143. [CrossRef]

(C) 2020 by the authors. Licensee MDPI, Basel, Switzerland. This article is an open access article distributed under the terms and conditions of the Creative Commons Attribution (CC BY) license (http://creativecommons.org/licenses/by/4.0/). 